\title{
Irrational austerity
}

\section{Innovative Firmen mit nachhaltigen Energietechnologien im Entwicklungsport- folio erhalten bislang wenig Unterstützung von Risikokapitalgebern. Eine genauere Betrachfung der Firmen zeigt, dass es aber eine ganze Reihe hervorragender Investment-Möglichkeiten gibt. Sie zu vernachlässigen, wäre falsch.}

W

Von Rolf Wüstenhagen ned the term Irrational Exuberance in 1996, he was sceptical of investors' over-enthusiasm about and consequently excessive valuations for young technology firms. Looking back, this was a farsighted statement, since huge amounts of investment money was flowing into the IT sector, and the question about long-term value creation was often left unanswered. Sustainability innovations on the other hand, like new energy and water technologies, have attracted relatively small amounts of money so far. Recently, there are signs of increasing investor interest, and particularly a number of independent and corporate Venture Capital funds supporting new ventures in this important sector. However, measured against the huge infrastructure investments that are needed to transform the energy sector, the current situation still seems to be characterized by irrational austerity, while there might actually be reason for rational exuberance.

According to the Cleantech Venture Monitor, a report published by a North American information provider, 1.1 billion US Dollar have been invested in 179 sustainability-oriented companies in 2002, with sustainable energy ventures accounting for 45 per cent of these investments (1). Those investments were reasonably profitable even in conventional terms: In an analysis of more than 800 ventures in the 1994 to 2004 period, it is indicated that median estimated IPO (initial public offering) returns were about 5.3 times on invested capital, and a hypothetical portfolio sustainability-related Venture Capital (VC) investments delivered an estimated internal rate of return of approximately 30 per cent (2). In Europe, the amount of sustainable venture capital investment is still somewhat lower, but more and more funds are being set up who dedicate their efforts to ventures in the sustainability sector. While there is no official definition of sustainability ventures, this category usually describes young privately-held companies, whose core product or technology represents a significant environmental improvement over currently dominating products, while at the same time having strong potential to become economically competitive and socially acceptable. Typical sectors include renewable energy, efficient water technologies, healthy food innovations or new lighter materials (3).

\section{Sustainable Energy Ventures - the Case of Enginion}

One example of a promising high-tech early-stage company in the sustainable energy sector is Berlin-based Enginion AG (4). Founded in 2000, the company's core product is the SteamCellTM, an innovative technology to address the large distributed power market. After six years of developing a $50 \mathrm{~kW}$ pre-prototype as a car engine at Volkswagen, Enginion was spun off to redesign the SteamCellTM as a six $\mathrm{kW}$ module for stationary applications. A particularly interesting target market is micro-CHP, i.e. small-scale combined heat and power generation for individual houses or small commercial buildings. Micro-CHP has several advantages when compared to the conventional model of central power generation and individual oil or gas heating. Since overall energy efficiency typically exceeds 85 per cent, microCHP reduces the use of fossil fuels and the emission of greenhouse gases. As energy is generated closer to the point of consumption, transmission and distribution losses are minimized and reliability may be increased. The holy grail of microCHP would be a technology with reasonable efficiency in the one to five $\mathrm{kW}$ scale (matching the electricity needs of residential or small commercial buildings) that would be mass-produced at low cost. Enginion seems to be a high-potential candidate for reaching this target, with a technology that avoids the electrochemical engineering challenges of a fuel cell and therefore might achieve lower cost within the near future. Enginion's second target market segment is auxiliary power units for upper-class cars and trucks. Despite being a young company, Enginion has succeeded in gathering a strong management team. Close links with the University of Technology in Berlin help them to get access to latest research and development knowledge, as well as sharing some of the infrastructure cost for engine development. The company's headquarter is currently located at the former headquarter of AEG, one of the pioneers of Germany's world-famous electrical engineering industry.

\section{Opportunities for Venture Capitalists}

Enginion is backed by a number of high-profile Venture Capitalists (VCs) that are investing in the energy sector. These include independent VCs as well as corporate VCs. The lead investor of Enginion's recent Series B financing round, SAM Private Equity, is a good example of an independent VC dedicated to sustainable technologies. Being one of the first movers in the European energy venture capital community, SAM Private Equity was launched in 2000 with two funds, one exclusively investing in sustainable energy ventures, the other one investing in energy, food and resource productivity. The total fund size is 86 million Euro, and the two funds have invested in 12 ventures to date. The geographical focus is on Europe and North America. Investors in the funds include both financial (e.g. the insurance companies SwissRe and Gerling, and the Canadian pension fund CDP Capital) and strategic investors (e.g. Hydro Quebec Capitech, EDF, Norsk Hydro Technology Ventures, and Mitsui). As for the financial investors, their motivation is typically one of portfolio diversification, while strategic investors are also looking for a window on new technology, with a view to potentially co-invest in some of the ventures as they mature. SAM Private Equity has witnessed substantial entrepreneurial activity in the market, receiving more than 1400 business plans of early- and expansion-stage sustainability ventures in its first three years of existence. Due to their strong in-house expertise, SAM was chosen as the lead-investor for the Enginion investment by both the company and the other investors in the round.

Among the corporate VCs investing in Enginion, E.On Venture Partners was the sole investor in the Series A financing round in 2001. Backed by E.On, one of the largest European electric utili- 
ties, E.On Venture Partners was founded in 2000 with a fund size of 25 million Euro and has invested in four ventures so far. Other corporate VCs participating in the Series B financing round include OPG Ventures, a subsidiary of the Canadian utility Ontario Power Generation, which is also an investor in SAM Private Equity; MVV Innovationsportfolio, the VC fund of MVV Energie AG, the Mannheim-based municipal utility; and Schneider Electric Ventures, the VC unit of the French electrical engineering company Schneider Electric. These corporate VC funds are typically relatively independent from their parent companies on an operational basis, but in their investment criteria they typically look for some strategic fit between the (future) activities of their parents and the $\mathrm{VC}$ investments. So while it is too early to conclude that sustainable energy and distributed power generation have become mainstream activities for Europe's largest utilities, there are clear early warning signals that they are preparing for upcoming fundamental changes.

\section{From Irrational Austerity to Rational Exuberance}

Looking ahead, we may expect that a few more extreme summers like 2003 with record temperatures and blackouts in the US and Europe, as well as a few more hurricanes like those hitting the US east coast in 2004 will help to move climate change and other sustainability challenges up on the public and political agenda. Consequently we might well see investors turn from irrational austerity to rational exuberance when it comes to sustainability ventures (5). This may then be the time for sober people like Alan Greenspan to call for caution again - for today's early sustainability investors, it will be harvesting season.

\section{Anmerkungen}

(1) Siehe www.cleantechventure.com

(2) LoGerfo, J./ Parker, N./ Propper de Callejon, D.: Cleantech Venture Investment - Patterns and Performance. New
York Toronto 2005.

(3) Moore, B./ Wüstenhagen, R.: Innovative and Sustainable Energy Technologies: The Role of Venture Capital. Business Strategy and the Environment, 13, 235-245. 2004

(4) Siehe www.enginion.com

(5) Wüstenhagen, R./ Teppo, T.: What makes a good industry for venture capitalists? Risk, return and time as factors determining the emergence of the European energy VC market. IWÖ-Diskussionsbeitrag Nr. 114, Universiẗ̈t St. Gallen, St. Gallen 2004, download at: www.iwoe.unisg.ch

\section{Der Autor}

Rolf Wüstenhagen ist stellvertretender Direktor des Instituts für Wirtschaft und Ökologie an der Universität St. Gallen.

Kontakt: Institut für Wirtschaft und Ökologie, Universität St. Gallen, Blumenbergplatz 9, CH-9000 St. Gallen. E-Mail: rolf.wuestenhagen@unisg.ch 
(c) 20I0 Authors; licensee IÖW and oekom verlag. This is an article distributed under the terms of the Creative Commons Attribution Non-Commercial No Derivates License (http://creativecommons.org/licenses/by-nc-nd/3.o/), which permits unrestricted use, distribution, and reproduction in any medium, provided the original work is properly cited. 